\title{
Eutrophication and Recovery in Experimental Lakes: Implications for Lake Management
}

\author{
D. W. Schindler \\ Science, New Series, Vol. 184, No. 4139. (May 24, 1974), pp. 897-899.
}

Stable URL:

http://links.jstor.org/sici?sici=0036-8075\%2819740524\%293\%3A184\%3A4139\%3C897\%3AEARIEL\%3E2.0.CO\%3B2-I

Science is currently published by American Association for the Advancement of Science.

Your use of the JSTOR archive indicates your acceptance of JSTOR's Terms and Conditions of Use, available at http://www.jstor.org/about/terms.html. JSTOR's Terms and Conditions of Use provides, in part, that unless you have obtained prior permission, you may not download an entire issue of a journal or multiple copies of articles, and you may use content in the JSTOR archive only for your personal, non-commercial use.

Please contact the publisher regarding any further use of this work. Publisher contact information may be obtained at http://www.jstor.org/journals/aaas.html.

Each copy of any part of a JSTOR transmission must contain the same copyright notice that appears on the screen or printed page of such transmission.

The JSTOR Archive is a trusted digital repository providing for long-term preservation and access to leading academic journals and scholarly literature from around the world. The Archive is supported by libraries, scholarly societies, publishers, and foundations. It is an initiative of JSTOR, a not-for-profit organization with a mission to help the scholarly community take advantage of advances in technology. For more information regarding JSTOR, please contact support@jstor.org. 
tion spectrophotometer equipped with a flameless mercury cell. Elemental mercury was observed. Also, a liquid trap of cysteine was placed in the flow system immediately before the acid-permanganate trap. This trap was counted along with the acid-pernanganate counted along with the acid-permanganate trap and showed no accumulated activity due cysteine trap would remove mercury and from the cuitcions but not elemental mercury from the nitrogen flow, the mercury species trapped by the oxidizing acid-permanganate trap must have been elemental mercury. wither direct measurements of evolved Hg with the atomic absorption spectrophotometer would have required excessively large concentrations of mercury, and the rate of release was so slow that this method of analysis was discontinued.
8. M. Schnitzer and S. V. Khan, Humic Substances in the Environment (Dekker. New York, 1972).

9. N. M. Atherton, P. A. Cranwell, A. J. Floyd, R. D. Haworth, Tetrahedron 23, 1653 (1967); R. D. Haworh, Telrahedron 23, 1653 (1967) R. Riffaldi and M. Schnitzer, Geoderma 8, (1972), M. Vil Cheshire and P. A. Cizanwell, . Soil Sci. 23, 424 (1972), B. R. Nagar, N. P. Khakhar, Indian $J$ 587 (1967)

10. B. R. Nagar, A. Chanorasekhara Rao, N. P Datta, Indian J. Chem. 9, 168 (1971).

11. Supported in part by funds from the Environmental Protection Agency under grant $R$ 800427. We thank P. W. Carr, E. G. Janzen, and L. R. Pomeroy for thoughtful discussion of this work.

10 December 1973: revised 21 January 1974 which has an extremely low content of dissolved inorganic carbon, to see whether shortage of carbon would prevent the eutrophication of such a lake (5). The lake was transformed into a teeming, green soup within weeks after nutrient additions were begun. Algal standing crops up to two orders of magnitude greater than those in unfertilized lakes of the area have been observed $(6,7)$. No increase in phosphate concentration was observed, and any added phosphate disappeared in minutes because of uptake by plankton (8). Gas-exchange studies revealed that some of the additional carbon required for production of this algal bloom was drawn from the atmosphere, and a comparison of dissolved inorganic carbon concentrations and parameters affecting gas exchange indicated that there was no possibility that shortage of carbon could prevent the eutrophication of the St. Lawrence Great Lakes or any other water body of economic importance (9).

Experiments conducted in smaller enclosures ( 2 to $3 \mathrm{~m}^{3}$ ) in the same lake revealed that if phosphorus was not supplied, algal blooms did not occur $(10)$. In order to test the validity of this conclusion on a whole lake, an experiment was begun in 1973 in another small lake, 226. This lake, which has two similar basins separated by a shallow neck (see Fig. 1), was divided into two equal areas by using a sea curtain $(60$ by $6 \mathrm{~m}$ ) of vinyl reinforced with nylon (Kepner Plastics, Torrance, California), which was sealed into the sediments and fastened to the bedrock in the narrow section of the lake. Beginning in late May 1973, additions of nitrogen and carbon were made equally to both basins, but phosphorus was added only to the northeast basin of the lake $(I /)$.

The photograph in Fig. 1 was taken on 4 September 1973, when a bloom of the blue-green alga Anabaena spiroides covered that basin receiving phosphorus. Throughout the year, phytoplankton species and standing crops in the basin that received only nitrogen and carbon remained similar to those before fertilization was begun, consisting chiefly of Tabellaria fenestrata, Synedra acus, and other diatoms. The results indicate the efficacy to be expected from controlling phosphorus content of the influents to such waters as a means of preventing eutrophication.

A common belief is that phosphate, returned from anoxic sediments in 
eutrophied lakes, would cause such lakes to retain their eutrophic character even if external sources of phosphorus were eliminated (12). Our results in 1 year from the fertilization of lake 227 showed that little or no phosphorus was returned from the sediments of that lake, even with anoxic periods of several months (13). Other studies have suggested that phosphorus return from sediments would not seriously delay the recovery of a lake from cultural eutrophication once major phosphorus sources were eradicated (14). A whole-lake experiment was therefore designed to test the speed of lake recovery and the efficiency of the sediments at removing and retaining phosphorus.

The phytoplankton and chemistry of lake 304 in its natural state were studied in 1969 and 1970 (4), In 1971 and 1972, phosphorus, nitrogen, and carbon were added to the lake (15). As in lakes 227 and 226, an algal bloom occurred in response to this application of fertilizer. In 1973, we continued to add nitrogen and carbon, but discontinued phosphorus additions, simulating conditions that might exist in a culturally eutrophied lake after phosphorus control measures were taken. The recovery of the lake was nearly complete, as the chlorophyll a concentrations indicate (Fig. 2). These results can be explained by our experiments in lake 227, which have shown that phosphate in the hypolimnion is taken up rapidly by microplankton (probably bacteria), then sedimented to the lake bottom, where it remains, regardless of oxygen concentration (16).

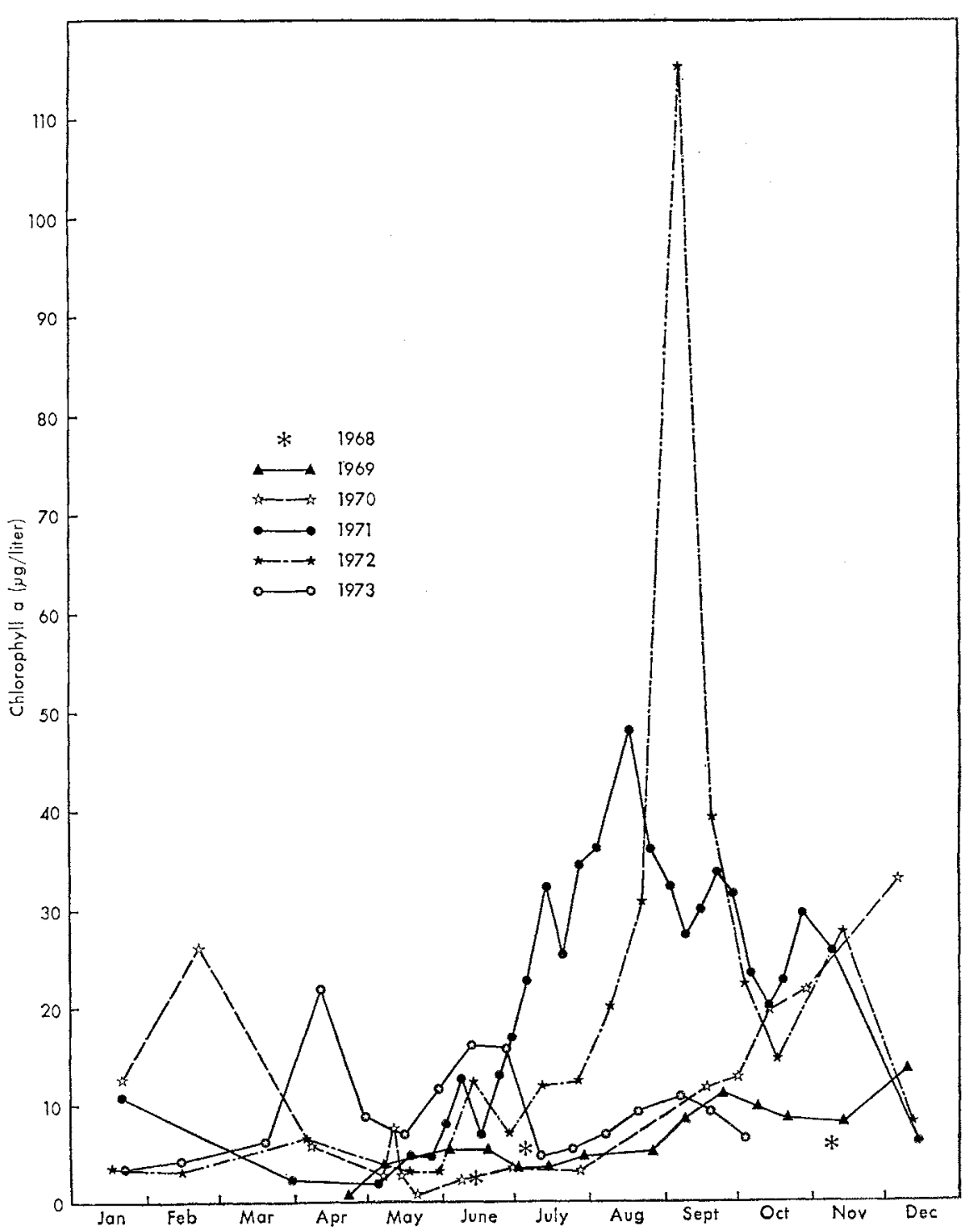

Fig. 2. Chlorophyll a concentrations in lake 304. In 1968, 1969, and 1970 the lake was not fertilized. In 1971 and 1972 , it received annual additions of $0.40 \mathrm{~g}$ of phosphorus, $5.2 \mathrm{~g}$ of nitrogen, and $5.5 \mathrm{~g}$ of carbon per square meter. In 1973, additions of nitrogen and carbon were continued at the same rate but phosphorus was not added.
Taken together, these results provide answers to the questions listed above. They suggest that cultural eutrophication problems might be solved simply and swiftly. In most lakes, reducing the phosphorus input could be expected to cause a proportional abatement in phytoplankton blooms and other symptoms of eutrophication (17). Fully 50 percent of the phosphorus coming into the St. Lawrence Great Lakes could be eliminated by simply banning or greatly reducing detergent phosphates, a step already taken in Canada and a few U.S. states (2). Most of the U.S. states, however, plan to remove phosphorus at the sewage treatment plant (18). While fine in principle, this scheme will take several years to implement to any effective degree, considering the time lags and uncertainty inevitable in financing, planning, and constructing such facilities. Numerous small sources, such as small communities and individual homes on septic systems, will escape phosphorus removal for some time longer. It appears that a basin-wide ban on detergent phosphates would quickly bring about a partial recovery of Lakes Erie and Ontario, perhaps as much as a decade before full-scale phosphorus control by other means is possible. Such a recovery would provide a savings of many millions of dollars, as well as restoring to some degree the beauty of these enormous resources.

D. W. SCHINDLER

Fisheries and Marine Service,

Freshwater Institute,

Winnipeg, Manitoba, Canada R3T 2N6

\section{References and Notes}

1. Great Lakes Water Quality Agreement with Annexes and Texts and Terms of Reference between the United States and Canada (Treaties and Other International Acts, Series 7312 , Government Printing Office, Washington, D.C. 1972).

2. Canada now prohibits the sale of detergents containing more than 2.2 percent phosphorus. This legislation became effective on 1 January 1973. In the Great Lakes Basin of the United States, only Indiana, New York, and Michigan have passed such legislation. Minnesota, Michigan, and Wisconsin plan to re move phosphorus at sewage treatment plants move phosphorus at sewage treatment plants after 1 January 1975, but only from municipa plants serving populations of more than 2000 to 2500 (18). Federal action will probably bc required if an effective phosphor
plan is to be implemented quickly.

3. For examples of the debate, see R. F. Legge and D. Dingeldein, Can. Res. Dev. 3 (No,

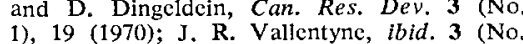
1), 19 (1970); J. R. Vallentyne, ibid. 3 (No. Eutrophication (Allen, Lawrence, Kan., 1972)

4. Issue No. 2 of J. Fish. Res. Board Can. 28 (1971) was on the Experimental Lakes Area project; also see H. Kling and S. K. Holmgren, Fish. Res. Board Can. Tech. Rep. No. 337 (1972).

5. Additions equivalent to $0.5 \mathrm{~g}$ of $\mathrm{PO}_{\mathrm{t}} \mathrm{-P}$ and $6.9 \mathrm{~g}$ of $\mathrm{NO}_{3:} \mathrm{N}$ per square meter of lake surface per year were nade over a $2 \mathrm{l}$-week period. This is five to ten times the inpur expected from natural sources and simulates 
the degree of nutrient enrichment in the Great Lakes [R. A. Vollenweider, Technical Report DAS/CSI/68.27 (Organisation for Economi Cooperation and Development, Paris, 1968)] Before fertilization, the concentration of dissolved inorganic carbon in the epilimnion of lake 227 was about $50 \mu$ mole/liter in mid summer. This is only about 2 to 3 percent of that found in the lower Great Lakes.

6. Most experts consider a lake to be eutrophic when algal blooms with more than $30 \mu \mathrm{g}$ of chlorophyll a per liter become common. Unfertilized lakes in the Experimental Lakes Area support a midsummer chlorophyll a concentration of only 1 to $5 \mu \mathrm{g} /$ iter. In lake 227. after fertilization, blooms with more than 100 g/liter have been common, and up to 100 ag/liter have been connon, and up to $300 \mu \mathrm{g} /$ liter periods (7)

. W. Schindler, F. A. J. Armstrong, S. K Holngren, G. J. Brunskill, J. Fish. Res. Board Can. 28, 173 (1971); D. W. Schindler, $\mathbf{H}$ Kling, R. V. Schmid, J. Prokopowich, V. E. Frost, R. A. Reid, M. Capel, ibid. 30, 141 (1973)

8. Because of the rapid turnover of phosphorus in many freshwater lakes $[F$. H. Rigler, Limnol. Oceanogr. 9, 511 (1964)] and uncertain methods of measurment [F. H. Rigler, Verh. Int. Ver. Limnol. 16, 465 (1966)] phosphate concentration appears to be unreliable as a widespread indicator of whether a lake will develop algal blooms (7)

9. D. W. Schindler, G. J. Brunskilt, S. Emerson, W. S. Broecker, T.-H. Peng, Science 177, 1192 (1972); S. Emerson, W. S. Broecke D. W. Schindler, J. Fish. Res. Board Can 30, 1475 (1973); W. S. Broecker, unpublished results.

10. D. W. Schindler (unpublished data) has found that if phosphorus is not supplied, no algal increases occur. If sufficient phosphorus is supplied, algal increases do occur, the magnitude being determined by available nitrogen, which in some cases may be fixed from the atmosphere. When both phosphorus and nitrogen are supplied in excess, algae -increase until light becomes limiting.

11. Additions equivalent to $3.16 \mathrm{~g}$ of $\mathrm{NO}_{3}-\mathrm{N}$ and $6.05 \mathrm{~g}$ of sucrose $\mathrm{C}$ per square meter per year were made to both basins, in 20 equal weekly increments. The northeast basin also received $0.59 \mathrm{~g} \mathrm{~m}^{-2}$ year-1 of $\mathrm{pO}_{-\mathrm{P}} \mathrm{P}$. The $\mathrm{N} / \mathrm{P}$ and $\mathrm{C} / \mathrm{P}$ ratios are greater than in $\mathrm{N} / \mathrm{P}$ and the quantity of $\mathrm{P}$ added is not exceptionally high for a culturally affected lake.

12. Sedimentary phosphate has been thought to dissolve under anoxic conditions by reducing ferric iron and forming $\mathrm{Fe}(\mathrm{OH})-\mathrm{PO}$ com-

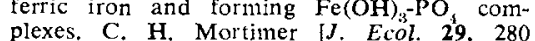
plexes. C. H. Mortimer [J. Ecol. 29, 280 inson $[A$ Treatise on Limnology (Wiley, New inson $[A$ Treatise on Limnology (Wiley, New York. 1957), vol. 1, chap. 12] explain this cycle.

13. Our preliminary results suggest that dissolution of iron-phosphate complexes followed by release of phosphate to the water column is prevented by the high demand of sediment bacteria for phosphate, and formation of humic acid-phosphate complexes,

14. Rapid recoveries were observed in Lake Washington in the state of Washington [W. T. Edmondson, Science 169, 690 (1970)] Tellersee, Germany IR. Liepolt, Verhandlungen Zellersee, Germany IR. Liepolt, Verhandlungen Symposion uber Gewassereutrophiertung (Salzburg, 1967)]; Pedersborg S $\phi$ and Lyngby S $\phi$, Dennark [H. Mathiesen, Mitt. Int. Verein. Limnol. 19, 161 (1971)]; and Little Otter Lake and Gravenhurst Bay, Ontario, Canada [M. F. P. Michalski, Ontario Ministry of Environment, personal communication; M. F. P. Michalski and N. Conroy, Proceedings 16th Conference on Great Lakes Research (1973), p. 934].

15. Additions equivalent to $0.40 \mathrm{~g}$ of $\mathrm{PO}-\mathrm{P}, 5.2$ $\mathrm{g}$ of $\mathrm{NH}_{3}-\mathrm{N}$, and $5.5 \mathrm{~g}$ of sucrose $\mathrm{C}$ per square meter of lake surface per year were made in 20 weekly increments.

16. D. W. Schindler, unpublished results

17. This would hold true only for lakes that are phosphorus-limited. Some waterways appear to have been so overwhelmed with phosphorus that it no longer limits phytoplankton production, and inputs of the element must be reduced enough for it to limit phytoplankton duced enough for it to linit phytoplankton growth before abatement would be proporVerh. Int. Ver. Limnol. 18, 355 (1972)].

18. Report to the International Joint Commission from the International Great Lakes Water from the International Great

21 December 1973

24 MAY 1974

\section{Opaline Sediments of the Southeastern Coastal Plain}

\section{and Horizon A: Biogenic Origin}

Abstract. Scanning electron microscope techniques show that Eocene opaline claystones (fuller's earth and buhrstone) of the Atlantic and Gulf Coastal Plain, deposits long considered volcanic in origin, are actually highly altered diatomites formed as transgressive facies in normal marine continental shelf environments. These findings are in agreement with a biogenic origin for time-equivalent horizon $A$ and $A^{\prime \prime}$ deep-sea cherts of the North Atlantic and Caribbean.

Opaline (cristobalite-rich) Eocene claystone deposits of the Atlantic and Gulf Coastal Plain have recently been cited in Science (1) and elsewhere (2) as examples of altered rhyolitic ashes which accumulated in nearshore or brackish coastal environments. Such ashes are also thought to have been distributed by atmospheric and water currents into the North Atlantic Ocean basin where they were presumably responsible for the formation of the cristobalite-rich, horizon A Eocene cherts $(1,3)$. We present evidence here to show that opaline claystones of the coastal plain are altered diatomites, not ashes, and that they formed in normal marine rather than in restricted coastal environments. Our evidence is compatible with a biogenic rather than a volcanic origin for the horizon $A$ cherts and their Caribbean equivalents (horizon $\mathrm{A}^{\prime \prime}$ ).

Opaline claystones are unusually porous, lightweight siliceous rocks which possess oil clarification properties (4). Accordingly, they have been referred to locally as fuller's earth (5) or buhrstone (6). Scanning electron microscopy of fracture surfaces of opaline claystones from 14 Southeastern Coastal Plain localities (Mississippi to South Carolina; see Table 1) reveals siliceous microfossils which occur as molds in 90 percent of the samples examined. The fossils are most abundant in samples which contain 60 to 90 percent $\mathrm{SiO}_{2}$. The opaline material is unidimensionally disordered alphacristobalite (7) in the form of bladed microspherulites (8). Most of the microfossil molds are of marine diatoms including large and small centrics (Fig. 1.A), pennates and forms which resemble Triceratium (Fig. 1B), and Actinoptychus (Fig. 1C). Sponge spicule (Fig. 1D) and radiolarian molds (9) are interspersed in the South Carolina and Alabama material. Clearly, the opaline claystones represent highly altered diatomite deposits rather than ash beds. Most microfossils in the deposits, however, have been completely destroyed by dissolution.

Siliceous microfossils have not been reported previously in South Carolina

Table 1. Opaline claystone samples which contain siliceous microfossil molds. The Black Mingo and McBean units were collected by S. D. Heron. All other samples were collected by the authors.

\begin{tabular}{lcc}
\hline Formation & Samples and localities & Age \\
\hline Nanafalia &
\end{tabular}

(Grampian Hills member)

Black Mingo

(opaline facies)

McBean

Tallahatta

Barnwell

(Twiggs Clay member)
GH-1 (Wilcox County, Ala.)

9-6-1 (Sandy Run Creek, S.C.); 9-9-1 (Big Beaver Creek, S.C.); 6-10-4, 9-11-4 (Little Beaver Creek, S.C.) ; 9-18-1, 9-18-2

(Bates Mill Creek, S.C.); 9-67-1, 9-67-2, 9-67-3 (Thelma Hill property, Calhoun County, S.C.) 9-68-2 (Dicks Swamp, S.C.); A-183-1 (Williamsburg Bridge, S.C.) ; 43-6-1, (Tavern Creek, S.C.); 43-7-5 (Holy Cross Church, Sumter County, S.C.)

A-3-1, A-3-2 (Early Branch, S.C.)

T-3 [Choetaw County, Ala;

locality 135 of Toulmin and

LaMoreaux (17) ]; I-10-12,

I-10-13, 33-1 (U.S. Highway

I-10, Meridian, Miss.)

KL-1 (Georgia-Tennessee Clay

Corporation pit, Wrens, $\mathrm{Ga}$.)
Middle Eocene

Late Paleocene

Early-Middle Eocene

Late Eocene 
http://www.jstor.org

\section{LINKED CITATIONS \\ - Page 1 of 1 -}

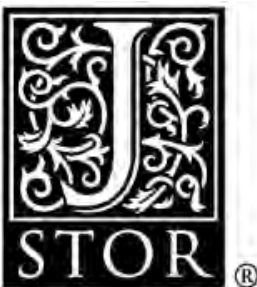

You have printed the following article:

Eutrophication and Recovery in Experimental Lakes: Implications for Lake Management D. W. Schindler

Science, New Series, Vol. 184, No. 4139. (May 24, 1974), pp. 897-899.

Stable URL:

http://links.jstor.org/sici?sici=0036-8075\%2819740524\%293\%3A184\%3A4139\%3C897\%3AEARIEL\%3E2.0.CO\%3B2-I

This article references the following linked citations. If you are trying to access articles from an off-campus location, you may be required to first logon via your library web site to access JSTOR. Please visit your library's website or contact a librarian to learn about options for remote access to JSTOR.

\section{References and Notes}

\footnotetext{
${ }^{9}$ Atmospheric Carbon Dioxide: Its Role in Maintaining Phytoplankton Standing Crops D. W. Schindler; G. J. Brunskill; S. Emerson; W. S. Broecker; T.-H. Peng Science, New Series, Vol. 177, No. 4055. (Sep. 29, 1972), pp. 1192-1194. Stable URL: http://links.jstor.org/sici?sici=0036-8075\%2819720929\%293\%3A177\%3A4055\%3C1192\%3AACDIRI\%3E2.0.CO\%3B2-F

${ }^{12}$ The Exchange of Dissolved Substances Between Mud and Water in Lakes Clifford H. Mortimer

The Journal of Ecology, Vol. 29, No. 2. (Aug., 1941), pp. 280-329.

Stable URL:

http://links.jstor.org/sici?sici=0022-0477\%28194108\%2929\%3A2\%3C280\%3ATEODSB\%3E2.0.CO\%3B2-P

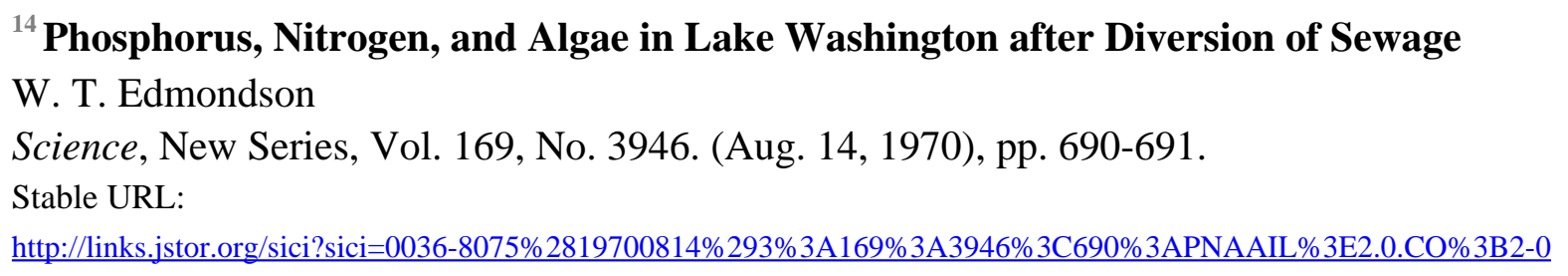

NOTE: The reference numbering from the original has been maintained in this citation list. 